\title{
Research
}

\section{Social Representations of the Diet in Patients with Diabetes Mellitus}

\author{
Donovan Casas Patino ${ }^{1,2 *}$, Alejandra Rodriguez Torres ${ }^{1}$, Georgina Contreras Landgrave ${ }^{1,2}$, Isaac Casas Patiño ${ }^{3}$, \\ Maria de los Angeles Maya Martinez ${ }^{1,2}$ \\ ${ }^{1}$ Universidad Autónoma del Estado de México, Mexico \\ ${ }^{2}$ Cuerpo Académico: Nutrición Humana, Educación y Salud Colectiva, Mexico \\ ${ }^{3}$ Escuela Nacional de Antropología e Historia, Mexico
}

\begin{abstract}
The "diet" is part of the collective's worldview, where culture shapes the webs of significance, giving way to a collective ideology internalised in each individual, which is fully accepted, assigned and assimilated by the collective. The diabetes mellitus is a condition whose importance lies in being one of the main causes of morbidity and mortality worldwide. This pathology is complex, but their struggle leads to the most basic and elemental: the "diet".
\end{abstract}

Methodology: Explore the common sense in relation to "diet" in patients with diabetes mellitus, via the Theory of Social Representations (SR). Semi-structured surveys were applied to 100 patients in three units of the Mexican Institute

\section{Introduction}

Diabetes Mellitus (DM) represents a challenge in the area of health each day worldwide. In Mexico the DM has been declared as a national epidemiological emergency focusing even more the policies and plans of action to a level of prevention and early diagnosis. Despite these efforts, its negative impact on the Mexican people can be understood by the following statistics: (a) Is the cause of a 14.4 percent of total mortality associated with DM in comparison to the rest of the world where it is located in a $3 \%$ of total mortality (Table 1). b) According to official data from 2005 to 2014 791, 738 have died of Mexicans by DM $[1,2]$. c) The DM is the first cause of healthy years of life lost in the country [3], and (d) the economic burden in spending to combat DM was estimated at 362 billion pesos $-18,100$ million [4], equivalent $2.25 \%$ of GDP (Gross Domestic Product) [5].

In Mexico the percentage probability of dying from DM is very high, and this has been the result of structural changes at the macro level - the neoliberal economic model that has created 55.3 million Mexicans in poverty-, meso level -health system collapsed, not preventive but healing- and micro very low per capita income per family (US\$2 per day) [6], which appears to have been the elements that give the social determination to the mexican collective diabetes mellitus.

\section{Diet tool in offensive to diabetes}

To reduce the DM, different international bodies recommend, focus on the reduction of the risk factors associated with the pathology, such as: unhealthy diets, physical inactivity, of Social Security of the State of Mexico, to define on the basis of the diabetic patients to the "diet".

Results: The term "diet" is a social construct, which builds and reinforces a social reality: poverty, inequality, and decontextualized biomedical control and public policies without social inclusive.

Conclusion: The end of this research reveals the thin threads of marginalization and ignomia of our collective suffering from diabetes, expose a inequality and insecurity, perpetuating a "diet" desregionalizada inadequate, contextualized, and far from the truth.

Keywords: Social representations; Diet; Diabetes mellitus

smoking, alcohol consumption, and an early diagnosis of the disease to prevent complications associated [7-11], reducing the need for treatments more expensive than [WHO 2016].

The modifications that humanity has had regard to the intake of food has conditioned an evolutionary adaptation in the whole planet Earth, and the collectives have been associated with this dietologica adaptation aspects of social constructions with respect to the imaginary and meanings in this activity. The Fed has built social relationships and socialization, and vice versa. These codes and relationships give construction to identities, as well the diet evolved to the pair of social and cultural development of mankind. The social constructs, meanings and signs, they are held to social conditions -class-, but also speaking of a regionalised, this determines a cultural, economic, political and family ties [12].

The diet is the key element of prevention, health promotion and healthy life styles to fight the DM, if health policies have been relying on healthy life styles, why the global collective continues toward the rise of DM?

The diet is an item that has been molded in each country of factual way, in Mexico the dietologica transition has made by class condition cheaper in time and money to eat a quick meal to prepare a healthy food [12]. Social Representations (SR) have an important role in the investigation of common sense which allows you to uncover the reality from its actors and be able to clarify the positive or negative domains of these social relations in Health. A study on the recent contributions to the theme of the power and their relationship from the theory of RS [13]. A 
Table 1: Comparative diabetes among countries, according to WHO data 2016.

\begin{tabular}{|c|c|c|c|}
\hline Country & $\begin{array}{c}\text { \% Proportional } \\
\text { Mortality Associated } \\
\text { with Diabetes }\end{array}$ & $\begin{array}{l}\text { Population } \\
\text { in Millions }\end{array}$ & $\begin{array}{c}\text { Total } \\
\text { mortality }\end{array}$ \\
\hline Mexico & 14.4 & 127 & 87,000 \\
\hline China & 2 & 1390 & 224,700 \\
\hline India & 2 & 1,311 & 220,000 \\
\hline Brazil & 6 & 208 & 72,700 \\
\hline $\begin{array}{l}\text { United states } \\
\text { of America }\end{array}$ & 3 & 322 & 71,000 \\
\hline Germany & 3 & 80 & 24,160 \\
\hline Japan & 1 & 127 & 14,720 \\
\hline France & 2 & 65 & 11,690 \\
\hline Spain & 3 & 46 & 10,420 \\
\hline Venezuela & 7 & 31 & 9,680 \\
\hline Russia & $>1$ & 143 & 9,680 \\
\hline Canadá & 3 & 35 & 6,610 \\
\hline Argentina & 3 & 43 & 6290 \\
\hline Colombia & 3 & 48 & 6,050 \\
\hline United kingdom & 1 & 64 & 6,030 \\
\hline Australia & 3 & 23 & 4,260 \\
\hline Haití & 5 & 10 & 4220 \\
\hline Saudi arabia & 5 & 31 & 4,050 \\
\hline Guatemala & 5 & 16 & 3,550 \\
\hline Ecuador & 4 & 16 & 3,300 \\
\hline Chile & 3 & 17 & 3,210 \\
\hline Peru & 2 & 31 & 2,950 \\
\hline Cuba & 3 & 11 & 2770 \\
\hline Switzerland & 2 & 8 & 1,350 \\
\hline
\end{tabular}

Source: Own; Of the World Health Organization report. Diabetes Country Profiles Report, 2016.

study on the structure of the social representations of the healthy eating into four groups and two contexts of Colombia, in order to identify the elements that organize the social knowledge on the subject [14]. This study showed the need of health practices as heuristic systems in which the knowledge consistency- behavior is solved in terms of the involvement of the action.

The social representations related to school feeding in the speeches of the school [15]. We identified three main concepts:1) "fast food" versus home-cooked food; 2) assessment of the fruit and 3 ) the role of the food. This study helps to understand the fact food in its symbolic dimension and social school feeding and its global orientation in relation to available food.

In an attempt to find the critical points of a healthy diet, Prada et al, conducted a study of the RS about healthy eating, using a descriptive-qualitative study and with the use of focus groups, it was possible to interpret that the healthy nutrition is considered as one that contains great variety and plenty of food. It is recognized the detrimental effect of the fats and sweets, however be prefixed as factors that interfere with the implementation of the lack of knowledge of the nutritional value of food, low incomes, lack of equipment and time for preparation.
Both from the biomedical point of view and from the sociocultural, anthropological, psychological and nutritional status, recognition of the role of a healthy diet to preserve health. The role of diet in diabetic patients is crucial as part of the treatment and metabolic control. Diabetic patients receive as part of its multidisciplinary care custom dietary guidance, however what will be the meaning and the beliefs that are in relation to the diet in this group of patients?

\section{Theoretical framework}

This research takes up the qualitative paradigm of the Theory of Social Representations (RS). Given that what interests us is a glimpse of the common sense of patients with DM in relation to the diet. Specifically we refer to the term coined by Sergei Moscovici, French social psychologist of Russian origin, which takes up a forgotten concept of Durkheim [16]. This theory arises in the field of social psychology to counteract the surge of individualization, due to the prevailing trend in this discipline was far removed from the social and was on his way to the individual. The representations are formed in the everyday experiences of the subjects, they may refer to large plots of reality, give meaning to the reality and change, are dialectical $[17,18]$ and of great utility to access the subjetivizadas forms or internalized the cultural fabric of the collective over the individual. Here the beliefs, myths, values, norms, practices, meanings, circulate on the field of the reality of the patient. The RS from a psychosocial perspective is a mechanism of cognition and instrument of socialization and communication, Moscovici defines it as: "... a particular mode of knowledge, whose function is to the development of behavior and communication between individuals" [19].

The RS integrates different cognitive concepts such as: attitude, opinion, identity, image, stereotypes, beliefs, symbols, etc., is located as a theoretical construct between the psychological and the social. So the social representation: " is a form of knowledge of common sense... it is in the form of social representations as social interaction influences the behavior (or thought) of the individuals involved in it, and it is trying to put into practice their rules when society forging relationships that should have among its individual members" [19]. The social representations are first described, then sort and, finally, explain all of the appropriation and reproduction of meanings related to an object under study.

\section{Methodological framework}

The study was carried out in the Family Medicine Units number 195, 193 and 73 of the Mexican Social Security Institute Middle Section, State of Mexico. The sample was obtained from a non-probabilistic way, the universe of the study population consisted of 100 patients with DM type 2 (without clinical sequelae). Within the inclusion criteria were patients less than 5 years of diagnosis of DM, without complications of the pathology of fund and who agreed to participate in the study informed consent.

For the core of the social representations of the diet used the model of Abric [20,21] by performing the following steps: 
the first phase consisted in a free association of words through a semi-structured interview with the purpose of finding the terms or phrases related to "diet", in a pilot study of 20 patients with DM. Once you have obtained all of the terms, expressions, or adjectives, they proceeded to analyze the system of categories by the frequency of the item and the range of association [21]. Subsequently, the realization of categories for analysis, according to the structure and function of the social representations of the meaning of diet. Then conducted an instrument (14 survey responses of association) obtained from the free association of words built from the first phase related to each category, this instrument was applied to 100 patients with DM informed consent. Finally, the survey was examined by association of categories with the speeches through the odds ratios (OR). This procedure was applied to the group of patients (N100), with the aim of comparing both figures to understand the meaning of each of the actors in their symbolic interactions with respect to the reconstruction of diet through the subject itself.

\section{Results}

The group of patients with DM for the free association
(N100), 72 were female and 28 male. The average age was 49 years $(\mathrm{SD}=9$ years), 61 were primary, 18 secondary schools, 12 high schools, professional 2 and 7 without studies. With regard to marital status, 479 married, single, divorced and widowed 8 9; 84 with regard to religion, profess the Catholic, Evangelical Protestants, 123 and 1 without religion or other not mentioned; in occupation 89 work in a formal manner, informally 7 and 4 are devoted to the home. With regard to the type family, by its composition, 58 patients were found with nuclear, 339 extensive and extensive.

In the first phase of free association in relation to "diet" in patients with DM, the results observed in Table 2.

With these words or phrases was achieved to form a group of categories from the responses evoked by patients with DM in relation to the role of "diet" (Table 3).

The frequency and percentages of Association of patients with DM, which show a presentation of frequencies for each speech analysis category (Table 3). Table 4 is the show ranges through bivariate analysis association between diet speeches and

Table 2: Free association of words in relation to "diet" in patients with DM (N20)

\begin{tabular}{|c|c|c|}
\hline Term or phrase & Frequency item & Range of association \\
\hline "...what that fills me with and is cheaper..." & 19 & 0.95 \\
\hline "...it is very difficult to follow the diet by the cost and time..." & 18 & 0.9 \\
\hline "...what you one can't eat..." & 18 & 0.9 \\
\hline "... I grant a lot of time in my diet and I end up abandoning it ..." & 17 & 0.85 \\
\hline "...money is not enough..." & 17 & 0.85 \\
\hline "... the nutritionist tells me to eat food, which is out of season ..." & 17 & 0.85 \\
\hline "... nutritious ..." & 17 & 0.85 \\
\hline $\begin{array}{l}\text { "... one eats what is not allowed because there is no where to eat healthily, because I } \\
\text { work ..." }\end{array}$ & 15 & 0.75 \\
\hline "...food..." & 12 & 0.6 \\
\hline "... what one should eat ..." & 11 & 0.55 \\
\hline "... what helps you feel better ..." & 10 & 0.5 \\
\hline "... is what the doctor tells me that I can eat ..." & 10 & 0.5 \\
\hline "... they are the foods that the nutritionist recommends me ..." & 9 & 0.45 \\
\hline "... diet is as important as medicine ..." & 7 & 0.35 \\
\hline
\end{tabular}

Table 3: Categories according to the function diet and associated words (N100) (own source).

\begin{tabular}{|c|c|c|c|}
\hline Category & Words or phrases & $f$ & $\%$ \\
\hline \multirow{3}{*}{ Identity } & "... what one can not eat ...", & 91 & 91.0 \\
\hline & "...food...", & 74 & 74.0 \\
\hline & "... nutritious ...", & 73 & 73.0 \\
\hline \multirow{3}{*}{ Activity } & "...it is very difficult to follow the diet by the cost and time...", & 89 & 89.0 \\
\hline & "... I grant a lot of time in my diet and I end up abandoning it ...", & 88 & 88.0 \\
\hline & "... what helps you feel better ...", & 80 & 80.0 \\
\hline \multirow{3}{*}{ Purpose } & "...what that fills me with and is cheaper..." & 88 & 88.0 \\
\hline & "... diet is as important as medicine ...", & 88 & 88.0 \\
\hline & "... what one should eat ...", & 86 & 86.0 \\
\hline \multirow[t]{2}{*}{ Rules/values } & "... one eats what is not allowed because there is no where to eat healthily, because I work ...", & 73 & 73.0 \\
\hline & "...money is not enough...", & 84 & 84.0 \\
\hline \multirow{3}{*}{$\begin{array}{l}\text { Position/ } \\
\text { relationship }\end{array}$} & "... is what the doctor tells me that I can eat ...", & 80 & 80.0 \\
\hline & "... they are the foods that the nutritionist recommends me ..." & 78 & 78.0 \\
\hline & "... the nutritionist tells me to eat food, which is out of season ...", & 84 & 84.0 \\
\hline
\end{tabular}


Table 4: Bivariate analysis of categories and association with the speech (N100).

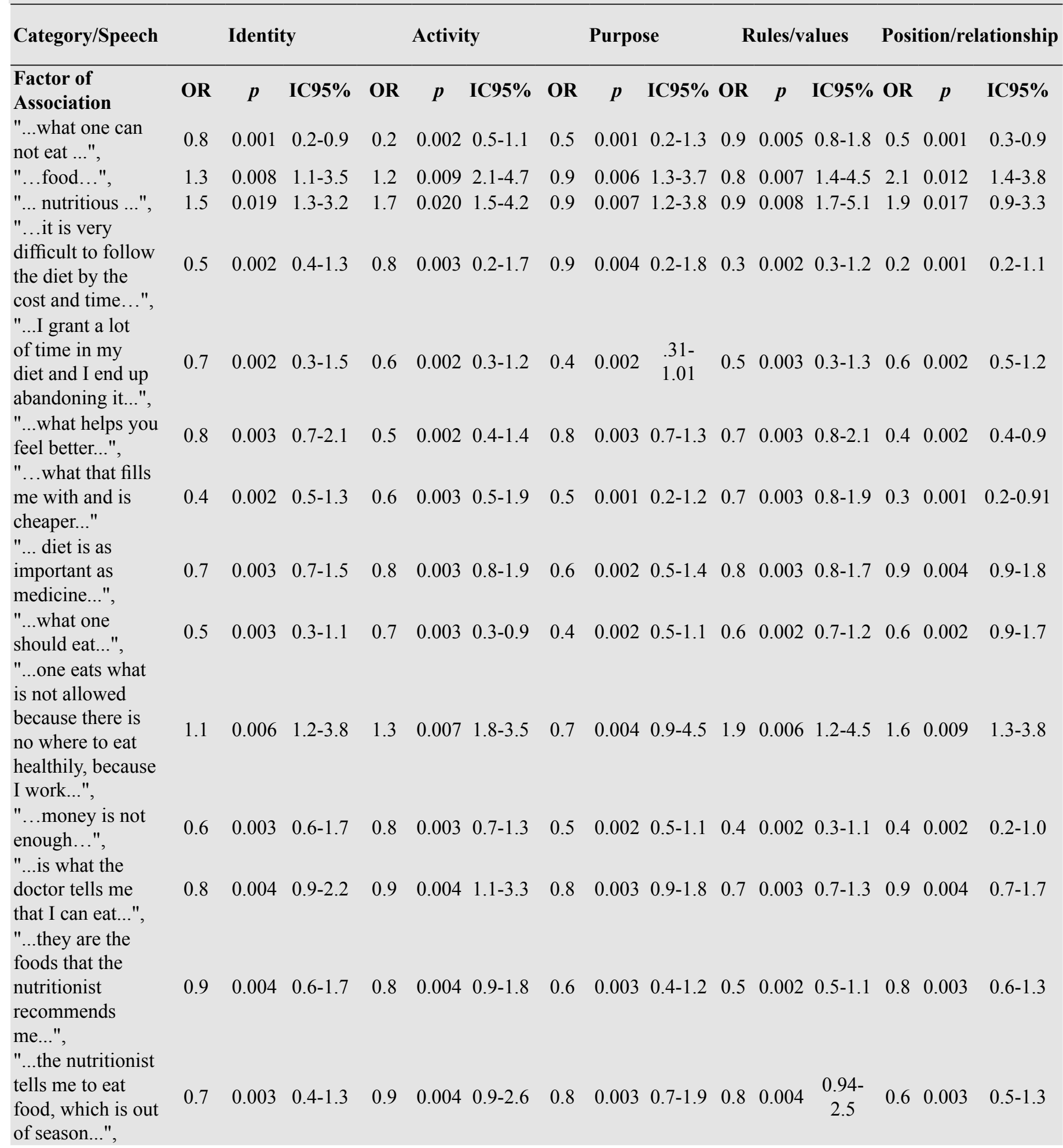

categories of structure, according to the associations obtained from the instrument (Table 4).

\section{Discussion}

To interpret the discursive Association of patients with DM with respect to diet, it is suitable to start through the categories of analysis preset, which might well be understood as a central thematic nuclei of the structure and function of the RS of this research, and thus to give way to the interpretation of the social scene of the patient.

\section{Identity}

Understood as construction from the collective that defines the relationship of themselves in relationship to each other or something, only for their vivid features (more or less permanent, inherent or attributed by cultural interaction) such as gender, race, ethnicity, religion, language, origin, in this case patient carrier of DM and the diet. The fragment of "diet" in this category is associated to a speech with a range of association very high to .... what one can not eat...,"This relationship linked 
to situations of socio-economic type at first, where experts say that ...the way of eating for our peoples is characterized by availability and accessibility, families eat what there is and what reaches... '[22], originating in this way conditions of social class according to economic perception, is worth mentioning that more than 15 years are experts on the subject claimed that in the Mexican population ....the dietary intake suggested a deficit of energy around $25 \%$, extremely low consumption of zinc, iron, vitamin $C$ and vitamin $A$ and consumption of protein and folic acid recommendations above... '[23], to date, Mexico ranks first worldwide in childhood obesity, and the second in obesity in adults, which causes a direct association with the largest number of cases of DM in the collective [24], This discursive panorama of the patients with DM also reflects a second time the transition dietologica cultural groups as a situation throughout our territory.

The "diet" is a social construct of an identity, in the country the food they eat almost every day families are: biscuits, tortillas of corn, soup, rice, sugar, beans, egg, soft drink, beer, onion, chile, potato and soluble coffee"[22], which are part of the culinary folklore of a country devoid of necessary nutrients which has been a consequence of the economic factor that has resulted in a transition towards the most economical or inexpensive dietologica: With the sharp drop in the gross domestic product (GDP) was observed a rapid increase of food poverty in Mexico, which went from 13.8\% of the population in $2006, " 18.2 \%$ in 2010, in parallel, lack food rates increased from 21.7 to $24.9 \%$ of the population between 2008 and 2010'[25].

Regarding the speeches .." food..." and ... nutritious...," studies confirm that in Mexico the teenagers have a little clear perception of what would be a healthy diet' [26] and in addition, "striking that while they know they are not healthy continue consuming them claiming that they do by the need of satisfying hunger, taste and economy" [27]. The Identity of diet in patients with DM is reconfigured for three times economically, socially, and culturally, thus giving incomparable and unimaginable a fateful moment of infamy food traits.

\section{Activity}

The description of ideological activity is typical in those groups that are defined by what they do about something, they are centered towards what makes them members of something patients with DM and diet. The most frequent phrases were: "... it is very difficult to follow the diet by the cost and time...,"...I grant a lot of time in my diet and I end up abandoning it..."and ... what helps you feel better...,"in this age of hypermodernity, time is fleeting and beyond our control [28]: Long work transfers, limited public transportation, schedules and working hours with extended hours and inadequate for basic functions of the family (coexistence, food supply, emotions, feelings, etc.), work stress, inadequate and uncomfortable schedules for Carry out a food break at work; All these factors determine fast diets of short consumption but full of energy fast-absorbing foods (Coca-Cola, instant soups, sweets, muffins, sandwiches, etc.), bordering collectives to submit to adaptive social development of hypermodernity of a diet Fleeting, rapid and inclusive marketing [29].

\section{Purpose}

Activities acquire an ideological and social meaning only if they have purposes (positive or negative). In this way, the ideological discourse of the groups will focus particularly on the (good or bad) purposes of their activities. The highest frequency in the discourse associated to this category was .... what that fills me with and is cheaper...,"...diet is as important as medicine...,"... what one should eat...,"In Mexico the socio-economic structure is a fundamental starting point for understanding this discourse, where the factors of social determination in this case to a "diet" have a direct impact in affirming that there is no importance in the preference of some diet, But this is changed to the first thing that can alleviate the hunger of the collectives. In that sense, it has been documented since the 1990s that food insecurity can increase the risk of obesity, diabetes, cancer and hypertension [30], Moreover, in those countries with a low GDP $(<\$ 750$ dollars per month), the prevalence of chronic energy deficiency is above the prevalence of obesity, making a direct correlation between empty energy and obesity development.

\section{Rules/values}

For a good part of the ideological discourses are meanings that involve norms and values about what we consider as good or bad, right or wrong, and what in our actions and purposes we try to respect or achieve. In the speeches the most frequent phrase was: ...one eats what is not allowed because there is no where to eat healthily, because I work...,"which is a reflection of the breaking of everything that is regulated within a dietary treatment of the patient with DM, for reasons such as work and absence of places where food can be acquired, thus drawing a state of frustration towards the search for habits recommended, despite having a pathology in the background [31].

\section{Position/relationship}

Through this category, it can be expected that it will be a special emphasis on group relations, conflict, polarization, and the negative presentation of the other (decertification), phrases found within this category such as: "...money is not enough...,"... is what the doctor tells me that I can eat...,"... they are the foods that the nutritionist recommends me..." and ...the nutritionist tells me to eat food, which is out of season...,"these speeches are engaged with fluctuating economic situations of international marketing further dipping to the groups. In addition there are speeches related to structures of BioPower, he is here confirmed the power structure medical hegemonic as the normalizer of a thought in relation to the mandatory a diet and not so the structure of a discourse of healthy eating. On the other hand the professional of the health dedicated to structure a knowledge scientific in benefit of the individual and collective is marked at the end of the relations of power that dominate them structures Dialogic of diet in patients with DM, this is of call it attention, since this professional is part fundamental of programs educational to level national, and apparently still not is part of the recognition social of them Collective [29].

Regarding the bivariate analysis of the discourses related to diet in patients with DM, we found a very strong association 
between all the categories and the following speeches, ... what one can not eat...,"... it is very difficult to follow the diet by the cost and time...,".... what that fills me with and is cheaper...,"... money is not enough... "and .... is what the doctor tells me that I can eat...," through this discursive analogies a network of meanings of a collective full of marginalization, ignominy and subjugation, where the Council of Representatives of the National Commission of Minimum Wages (Conasami) agreed an increase to the workers' salary of 3.9\% this Means 4 pesos -0.25 dollars. This is equivalent to the purchasing power of: 5 tortillas or a non-sweet salt loaf, u, 8 sweet solid candies, or 1 banana or 8 grapes or $1 / 4$ papaya or watermelon or melon or pineapple; And the other side does not reach this increase for: a subway ticket, travel by public transport [taxi, pesero, micro, truck], not a piece of pork or beef or chicken or fish, really does not serve this increase; So the phenomenal is that the infamy of the past is present, it is said by the country's legislature .... the purpose of this increase is to make it possible to recover the purchasing power of salaried workers who receive a general minimum wage..."[32]. The discursive structure emphasizes the factors of social determination of health, in this case the economic which refers to the perception of a collective that builds through the common sense the failure of policies not only health, but of a general collective perception.

Before this perplexing entity, the President of Mexico Enrique Peña Nieto, the Secretary of Health Jose Narro Robles and the Senators Chamber, they requested ddditional measures'against the DM and so was, is declared in Mexico national epidemiological emergency [14 November 2016] this alerted by the Mexican Government [33], fits mention that previously never is had presented a case similar by disease chronic not transmissible [CNCD], since all offensive to these is preventable, but in this case the political chosen began its road of alert, vulnerability and follow-up, that do in a country, lashed by violence, corruption, plunder to the purse public, null political of inclusion social real and submission social, the "diet" confirms that the DM and them CNCD will continue to in increase, until not is improves the quality of life of all them Mexican.

\section{Conclusion}

Currently, priority is that the fight against the epidemic of diabetes mellitus (sugar bitter) must be carried out through a healthy diet, nutritious, affordable, and season; but the social construction of reality of common sense shows that this is far from the dogmatic statements of what political scientist: "biased regulations favor the economic interests above the health of the people" [34]. The end of this research reveals that the thin threads of marginalization and ignomia of our collective living with diabetes, are critical nodes to really consider the diet as a tool to combat, control, and prevention of chronic noncommunicable disease in the most challenging of health systems in the coming years.

\section{References}

1. ADA (2009) Standards of medical care in diabetes. American Diabetes Association. Diabetes Care. 32: S13-S61.
2. INEGI (Instituto Nacional Estadística Geografía e Informacion) (2017) Estadística de Mortalidad en México 2016. Base de Datos INEGI.

3. Gomez H, Fullman N, Lamadrid H (2013) Dissonant health transition in the states of Mexico, 1990-2013: A systematic analysis for the global burden of disease study 2013. Lancet. 2016.

4. Hernandez A, Gutierrez J, Reynoso N (2013) Diabetes mellitus in México. Status of the epidemic. Salud Publica Mex. 55: S129-S136.

5. Barraza M, Guajardo V, Pico J (2013) Carga económica de la diabetes mellitus en México, DF: Funsalud.

6. CONEVAL (2014) (Consejo Nacional de Evaluación de la Política de Desarrollo Social). Dirección de informacion y comunicación social: Coneval informa los resultados de la medición de pobreza. Comunicado de Prensa No 005.

7. IDF (2015) Atlas de la Diabetes de la Federación Internacional de Diabetes, IDF ( $7^{\mathrm{a}}$ edición).

8. Bengoa J (2008) Guías de alimentación. Caracas: Fundación Cavendes.

9. World Cancer Research Fund/American Institute for Cancer Research (2009) Food, nutrition and the prevention of cancer: A global perspective. Washington, DC, American Institute for Cancer Research.

10. Romieu I (2011) Diet and breast cancer. Salud Pública de México. 53: 430-439.

11. Ministério Da Saúde (2013) Dietary guidelines for the Brazilian population. Brazilian Ministry of Health.

12. Casas D, Rodríguez A (2014) Significado de la dieta en pacientes con obesidad. Ciencia desde el Occidente. 1: 5360.

13. Andreatta M (2013) La alimentación y sus vínculos con la salud desde la Teoría de las Representaciones Sociales. DIAETA. 31:42-49.

14. Parales C (2006) Representaciones sociales del comer saludablemente: un estudio empírico. Univ Psychol. 5: 613626.

15. Theodore F, Bonvecchio A, Blanco I, Carreto Y (2011) Representaciones sociales relacionadas con la alimentación escolar: el caso de las escuelas públicas de la Ciudad de México. Salud Colectiva. 7: 215-229.

16. Timasheff $\mathrm{N}$ (2006) La teoría sociológica. 21 reimp. Editorial Fondo de Cultura Económica. México, D.F. 141-154.

17. Delval J (2000) Aprender en la vida y en la escuela.1era ed. Editorial Morata, Madrid, España.

18. Moscovici S (1988) Notes towards a description of social representations. Eur J Soc Psychol. 18: 211-250.

19. Moscovici S (1994) Psicología Social Tomo.

20. Abric J (2001) Prácticas sociales y representaciones. México DF: Coyoacán.

21. Revilla A, Luna Del Catillo J, Bailón E, Medina M (2005) 
Validación del cuestionario MOS de apoyo social en atención primaria. Med Fam. 6: 10-18.

22. Enciso A (2013) Promueven programas consume de alimentos que ocasionan obesidad. Refresco y galletas, dieta en la Costa Chica y la Montaña de Guerrero, revela estudio. Periódico La Jornada. Sección Sociedad y Justicia.

23. Rivera J (2000) La situación alimentaria en México. Revista de Salud Pública de México. 3: 34-49.

24. UNICEF (2014) Salud y nutrición. El doble reto de la malnutrición y la obesidad. Boletín Informativo.

25. Urquía N (2014) La seguridad alimentaria en México. Salud Pública de México. 56: 92-98.

26. Lagunas E, Luyuando J. Alimentos saludables: la percepción de los jóvenes adolescentes en Monterrey, Nuevo León. Estudios Sociales.

27. Contreras G, Camacho J, Ibarra L, López L, Escoto (2013) Los hábitos de estudiantes universitarios. Revista Unam. 14: 1607-1622.

28. Lipovetsky G. La felicidad paradójica. 2 ed. Editorial Anagrama, Barcelona, España.
29. Casas D, Oliveira C, Rodríguez A, Contreras G (2015b) Representaciones Sociales de la dieta en pacientes con Obesidad: caso internacional México [Chalco] y Brazil. Parte II. Revista Archivos de Investigacion Materno Infantil. 7: 77-84.

30. Dietz W (2016) Does hunger cause obesity? Rev Med Pedia 95: 766-779.

31. Díaz J (2007) Estrés Alimentario y salud laboral vs. Estrés laboral y alimentación equilibrada. Med Segur Trab. 53: 9399.

32. Editorial de la Jornada (2016) Conasami otorga incremento de 3.9 por ciento; será de 80.04 pesos diarios a partir de enero. La Jornada Maya.

33. Cruz Á (2016) Riesgo de diabetes en uno de cada tres niños nacidos a partir de 2010: la industria de alimentos y bebidas obstaculiza la estrategia nacional de prevención y control, acusa.

34. Cruz Á (2016) México, en emergencia epidemiológica por diabetes: Ssa. La Jornada Sección Opinión.

Address of Correspondence: Donovan Casas Patino, Department of Sociology of Health of the University Center Amecameca UAEM, Colonia, US, Tel: 597-9782158059, E-mail: capo730211@yahoo.es

Submitted: February 06, 2016; Accepted: February 27, 2017; Published: March 06, 2017

Special issue title: Nursing and Health Care Diversity Handled by Editor(s): Dr. Andrew Ashim Roy, Assistant Professor of Community Health Institute of Health Science, Bangladesh 